\title{
Evaluation of Coping Strategies with Stress of Parents Who Have Mentally Disabled Children in Northern Cyprus
}

\author{
Ramazan Atasoy ${ }^{1, *}$, Cengiz Sevim ${ }^{2}$ \\ ${ }^{1}$ Turkish MoNE, Ankara, Turkey \\ ${ }^{2}$ Turkish MoNE, Bursa, Turkey
}

Copyright $\bigcirc 2018$ by authors, all rights reserved. Authors agree that this article remains permanently open access under the terms of the Creative Commons Attribution License 4.0 International License

\begin{abstract}
In this research, it's aimed to determine the problems that faced by parents who have mentally disabled children and evaluate coping strategies of them. Interview technique is performed in this study which is designed in qualitative model. Study group which was determined by purposeful sampling method is consisted from the parents of mentally disabled children who are studying in private education centres in TRNC. Data are evaluated by content analysis. According to the findings in this research, the problems of parents which they faced are determined as related with their each other that are educational, physical, psychological, sociological, economical and also health care problems and problems with siblings. It's found that parents are focused especially on educational problems. According to the results that were emerged in the research that educational problems are cumulated in two categories as problems related with the quality of education that given to children and acceptance of children in educational environment, and the problems on the need for training of parents. It's determined in this research that increasing educational and consciousness level of parents has more efficiency for coping with stress. Also it's found that, parents use emotional focused coping strategies for struggle with mental disability which is the main source of stress; but they prefer problem focused coping strategies for struggling with external problems that causes increasing the stress. It's suggested that qualified and continuous educational service for both mentally disabled children and their parents could direct them to problem focused coping strategies instead of emotional focused coping strategies.
\end{abstract}

Keywords Emotional Focused Coping Strategies, Problem Focused Coping Strategies, Mental Disabilities, Education

\section{Introduction}

Future of the society depends on qualified training of children. The first education is given in family environment. One of the most important aims of family members is to provide a healthy environment for the growing up of individuals [1]. But many children are borne with disabilities or become disabled for various reasons. One of these disabilities is mental disability. Mental disability is a common disability and it's a situation that causes limitation on mental functions and skills for conceptual, social and practical harmony [2]. Mental disabled people have difficulties in different grades for self-care, communication, keeping self-health, and solving problems in daily life $[2,3]$. There is a great responsibility and mission for parents in the period of training and gaining to the society and coping with the problems that they experienced.

Mental disability is defined as limitations on both mental functions and adaptive fields occur before 18 years old in the instructions of AAMR (Association of American Mental Disability) and AAIDD (American Association of Mental and Developmental Inadequacy). Limitations on mental functions are the limitations that occur in basic processing skills. Adaptive skills fields are listed as communication, social skills, social benefits, health, spare times and job [2]. Mental disability could be defined as "inadequacy for solving daily problems" in this context.

An individual with mental disability is defined as individual who has two levels under the standard deviation for mental functions in Special Education Services Instruction of National Education Ministry which was published in 2006. According to the differentiation on these mental functions an individual with mental disability is defined as who has limitations or lack on conceptual, social or practical adaptation and these aspects of them has emerged before age 18 and who needs special 
education and supportive education [4].

Mental disability is also defined as being in a situation that significantly lowers level for mental functions in the instruction of AAIDD 2002. Mentally disabled individuals are under the $97 \%$ of the society for performing mental functions and mental capacity. Intelligence tests are used for diagnosing of mental disability. Individuals who have 70 and lower scores in standard intelligence test which evaluates IQ score on 100 point are assessed as mentally disabled [5].

There are different approaches directed to classification of mentally disabled children. In The literature there are classifications for medical, psychological and educational fields. Performing of that kind of classification is deemed as important for determining of differences belonged to each of children and providing special educational possibilities for them. Most accepting method for classification of mentally disabled individuals in recent years is classification for educational diagnosis classification. Classification according to approach is shown in Table 1.

Table 1. Classifications directed to Mentally Disabled Individuals

\begin{tabular}{|c|c|c|c|}
\hline IQ & $\begin{array}{c}\text { Medical } \\
\text { Diagnosis }\end{array}$ & $\begin{array}{c}\text { Psychological } \\
\text { Diagnosis }\end{array}$ & $\begin{array}{c}\text { Educational } \\
\text { Diagnosis }\end{array}$ \\
\hline $70-55$ & Debilitated & $\begin{array}{c}\text { Mildly mental } \\
\text { disabled }\end{array}$ & Trainable \\
\hline $55-35$ & Imbecile & $\begin{array}{c}\text { Moderate } \\
\text { mental disabled }\end{array}$ & Educable \\
\hline $35-25$ & Idiot & $\begin{array}{c}\text { Seriously } \\
\text { mental disabled }\end{array}$ & Depended \\
\hline $25-0$ & Idiot & $\begin{array}{c}\text { Seriously heavy } \\
\text { mental disabled }\end{array}$ & $\begin{array}{c}\text { Fully } \\
\text { Dependent }\end{array}$ \\
\hline
\end{tabular}

Human is a social existence. This existence is formed according to relationship of the other individuals and environmental factors. These economic, social, cultural and technological changes that experienced nowadays are the factors that formed the life of an individual. Human beings affected by this change inevitably. Alteration and development on living conditions force and threat the physical and physiological limits of individuals. Human being should live by forcing their limitation in every situation and in every stage of the life. This is the reason of stress. Therefore stress is assumed as a disease of modern ages and daily life [6]. Stress is a reality of human life and has become a concept that confronted frequently in our both daily life and business environment [7].

Stress is a situation that emerged when the limitation of an individual has forced both physically and psychologically [8]. In another word stress is a widespread response of an individual to every changing in his /her life [9].

Some psychological and physical disease could be occurring in person who exposed and has to live with stress. Person could be in a burnout period if the factors which cause stress and stress would keep its effect on the person [10]. In stressful situation, there would be fear, anxiety or tension that are psychological responses such as physiological response those are sweating, blushing and increasing of heart rate according to characteristic of a person. Instead of complaining and bewailing from the confronted problem, person who is under the stress should focus both emotional and mental energy on methods which are directed to solving the problem [11]. However stress in a certain level is necessary to increase the quality of life.

Coping with negativities which cause stress is define as stress management. In other statement; stress management is defined as changing the situation that causes stress or the responses to that situation for the sense of coping with stress and increasing the life quality. Stress management is expressed as coping with negativity that causes stress [12]. The aim of stress management is to increase the quality of life of individuals. Another goal of the stress management is to help for rightly defining of the problems and protect the individuals from both physical and psychological damages. The other object of stress management is to present the causes that create stress and responses to them and teaching and developing methods for coping with them [13].

The first step for coping with stress is to realize the stress and find out how stress affects the person. Different coping strategies which could be varied from person to person could be performed after this first stage [14]. An individual doesn't give reaction in same way whenever they confronted with a stressful situation. Therefore individuals comprehend in different ways the stress. This comprehension varies with age gender, culture and social environment where the individual lives [15].

Literature describes the ways of coping with stress in different forms $[8,16,17,18]$. It's possible to classify the methods for coping with stress as problem focused coping strategies and emotional coping strategies with stress. Problem focused coping is aimed to decrease the effect of source of stress or to develop coping strategies of the person in stressful situation. Individuals who prefer problem focused coping strategy which defined as active coping strategy are try to understand and change source of stress directly [14, 17, 19]. Emotion focused coping strategy includes to decrease or regulate the emotional results of stressful situation. The individual tries to decrease or change the direction of the emotional results of the stressful situation by emotion focused coping strategy [20]. The most significant difference between those two method is while active, logic and conscious methods are applying that directed to change the stressful situation with problem focused coping strategy, passive methods prefer in emotion focused coping strategy [17]. While problem focused strategy intends to change the situation, emotion focused strategy intends to change the reactions to the stressful situation.

Mental disability is unchangeable and persistent situation according to Friedrich et al. [16]. A persistent disability is a source of stress that needs to be constantly 
challenged by parents. Families often remain incapable to cope with this intense stressful, long-term problem and experience a variety of behavioural and emotional problems. A child with mental disability depends to parents and surroundings in a certain extent $[21,22]$. It has been shown that milieu of the children with mental disability experience stress and has difficulties to perform their roles both in family life and their social life and experience social exclusion in literature $[23,24,25,26,27,28,29$, 30].

The problems which parents of children with mental disability are confronted are determined and strategies for coping with stress of them are evaluated in this research. In order to reach this aim, the answers to the following questions are searched.

1. What are the problems that you confronted as a family of a mentally disabled child?

2. What are the signs for stress on parents of a mentally disabled child?

3. What kind of methods do you exert to cope with stress through disability of your child?

\section{Method}

\subsection{Model of the Research}

This research that evaluates the stress management of the parents of mentally disabled children in Turkish Republic of Northern Cyprus is performed in qualitative research methodology, pattern of phenomenology and by interview technique. Researches of phenomenology reveal examples, explanations and experiences which could help to understand and recognize a phenomenon [31]. The object of the interview technique is to enter into the inner world and to understand point of view of an individual [32]. This research has been modelled as shown in figure 1 below in the direction of the findings.

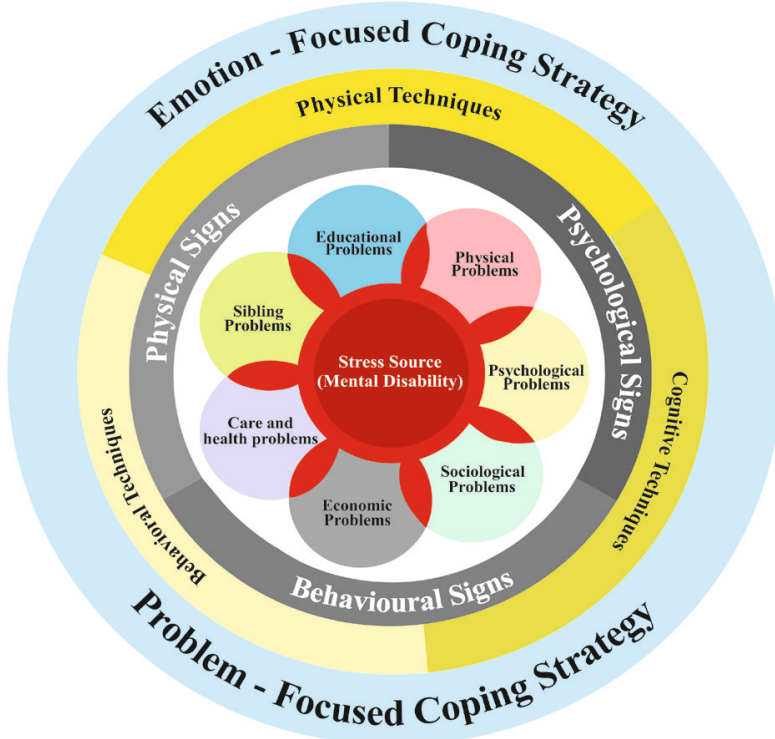

Figure 1. Model of the research
It is revealed that main resource of the stress that parents have experienced is mental disability of their children in this model. The other stress factors which are developed consequence to this main stress resource are problems which have interwoven characteristic. Respectively cognitive, material and behavioural strategies are applied as emotion focused coping strategies for coping with mental disability. Parents resort to problem-focused or emotion-focused strategies for coping with external or relative stressors depending on circumstances.

\subsection{Universe of the Research and Study Group}

Study of the research is parents of 304 of mental disabled students who are studying in Special Education Centres in TRNC. Purpose sampling method was performed for creating the study group of the research. Maximum diversity and easily accessibility is considered for assigning of the sampling [32]. The sampling is consisted from parents of students who have diagnosed for diverse mental disability ( $\mathrm{n}=21$ mother, $\mathrm{n}=4$ father). The interviews were conducted on the basis of volunteerism with the parents of students. Descriptive information for participants is given in Table 2 .

Table 2. Descriptive Aspects of Parents who participates to the research

\begin{tabular}{|c|c|c|c|}
\hline Variables & & $\mathbf{n}$ & $\%$ \\
\hline \multirow{4}{*}{$\begin{array}{l}\text { Caregiver to the } \\
\text { child }\end{array}$} & Mother & 5 & 20 \\
\hline & Father & 0 & 0 \\
\hline & $\begin{array}{l}\text { Both Mother and } \\
\text { Mother }\end{array}$ & 9 & 36 \\
\hline & $\begin{array}{c}\text { Mother and another } \\
\text { member of the family } \\
\text { or caretaker }\end{array}$ & 11 & 44 \\
\hline \multirow{4}{*}{$\begin{array}{c}\text { Educational Level } \\
\text { of Parents }\end{array}$} & Elementary and less & 15 & 60 \\
\hline & Secondary School & 6 & 24 \\
\hline & High School & 3 & 12 \\
\hline & University & 1 & 4 \\
\hline \multirow{3}{*}{$\begin{array}{l}\text { Economical Level } \\
\text { of Parents }\end{array}$} & Lower & 12 & 48 \\
\hline & Medium & 9 & 36 \\
\hline & Higher & 4 & 16 \\
\hline \multirow{7}{*}{$\begin{array}{l}\text { First time to get } \\
\text { aid for the } \\
\text { problem of child }\end{array}$} & $0-12$ month & 5 & 20 \\
\hline & 13-24 month & 4 & 16 \\
\hline & 25-36 month & 8 & 32 \\
\hline & $37-48$ month & 3 & 12 \\
\hline & 49-60 month & 2 & 8 \\
\hline & 60-72 month & 2 & 8 \\
\hline & Don't remembered & 1 & 4 \\
\hline \multirow{4}{*}{$\begin{array}{c}\text { Age at which } \\
\text { parents discern } \\
\text { disability in their } \\
\text { children }\end{array}$} & In pregnancy & 1 & 4 \\
\hline & At delivery & 7 & 28 \\
\hline & $0-1$ age & 11 & 44 \\
\hline & $1+$ age & 6 & 24 \\
\hline
\end{tabular}

According to the Table 2, these results are found: Caregiving is mostly done by "mother and the other 
members of the family" ( $\mathrm{n}=11 ; 44 \%)$; education level of the families are mostly elementary school and under elementary school level $(\mathrm{n}=15 ; 60 \%)$; Most of the parents have lower income $(\mathrm{n}=12 ; 48 \%)$. Usually 25 th 36th month range is most common period in which parents receive help at first time for their children $(n=8$; $36 \%$ ) and parents noticed the disability of their children in $0-1$ age range $(\mathrm{n}=11 ; 44 \%)$.

\subsection{Data Collection Tools and Process}

"Semi-structured Interview Form" which developed by researchers was used for data collection. In order to ensure the validity of the interview form, two expert opinions were taken to ensure that questions were reasonably relevant and understandable, pilot interviews were held with three participants and final form was given. The survey data were collected from 20 September to 20 December 2017 at the times when the participants were available and interviews were held at predetermined locations. In order to obtain rich data, interviews with parents of mental disabled children were held in a comfortable environment and in a face - to -face conversation ambience. Every interview has endured about $25-30$ minutes. Data were collected by voice recording and noting. Speeches of the participants are recorded without changing of their authenticity.

\subsection{Analysis of the Data}

Data which were collected by semi-structured interview technique were analysed by content analysis. The aim of the content analysis is to reach the concepts that could explain the collected data and relations between concepts [31]. Participants were coded as $\left[\mathrm{E}_{1}\right],\left[\mathrm{E}_{2}\right] \ldots,\left[\mathrm{E}_{25}\right]$. Collected data in the research were also codified. Codes are categorized by cross - sectioning method after arranged in a format that suitable to the content. Then data of the research were read by two different researchers and made codifying by them. $84 \%$ of similarity has found between codifying of the researchers. Over $70 \%$ of this similarity reflects the reliability of the study [33]. Consensus and disagreements were discussed and necessary adjustments have done.

\section{Findings}

\subsection{Confronted Problems Types}

Seven categories consisted relevant answers of parents of mental disabled children to confronted problems related with the first question of the research. Frequency of the problems according to the types is given in the Table 3.

There are 92 different problems when the table 3 is examined. Problems which are stated by participants are educational problems ( $\mathrm{f}=18)$, physical problems $(\mathrm{f}=15)$, psychological problems $(\mathrm{f}=14)$, sociological problems $(\mathrm{f}=13)$, economical problems $(\mathrm{f}=13)$, Caregiving and health problems $(\mathrm{f}=11)$ and sibling problems $(\mathrm{f}=8)$.

Table 3. Frequencies of the problems according to the types

\begin{tabular}{|c|c|c|c|c|c|c|c|}
\hline \multicolumn{9}{|c|}{ Confronted Problem Types } \\
\hline Educational & Physical & Psychological & Sociological & Economical & Care-Health & Siblings & $\mathrm{n}$ \\
\hline 18 & 15 & 14 & 13 & 13 & 11 & 8 \\
\hline
\end{tabular}




\subsubsection{Educational Problems}

With respect to the opinion of the parents it's possible to collect the problems into two different categories which are problems related with the education of mental disabled children and problems related with education of parents.

It's seen that difficulties for school enrolment and accepting into the classes are the main problems which are the most common confronted problem of parents of children with mental disability. It's found that especially school administrators and classroom teachers don't prefer to accept the mentally disabled children into educational environment and show resistance for not to accept them. Also it's revealed that there are problems related with the quality and characteristic of education that given to the mentally disabled children. In this context inadequacy of the period of education, lack of the capacity of teachers, and needs for special supportive education and isolation of mentally disabled children from educational activities are come to the forefront in this research. Some participants expressed their opinions related with education of mentally disabled children as below:

"They didn't accept my child to school $\left[\mathrm{E}_{8} ; \mathrm{E}_{10} ; \mathrm{E}_{11}\right.$ $E_{24}$." "They didn't accept Yilmaz for he has disposable nappies. I talked with $3-4$ teachers but they didn't $\left[E_{6}\right]$ ". "“... Once he fainted in the day care centre of municipality then they didn't want to accept him again $\left[\mathrm{E}_{7}\right]$." "Schools didn't accept us. We applied to the ministry for get acceptance from schools. They send us to Polatpaşa Elementary School. Then we went to Şehit Zeki Salih. I explained the situation of my child. Then they accepted. [E $\left.\mathrm{E}_{4}\right]$ ". "WE have had problem for accepting into the day care centre. All of the centres have refused us from beginning. Then a centre has accepted us. We had too much problem in first class of elementary school. They didn't want to take into the classroom. We registered by forcibly to the class. One week a teacher has accepted him in her class, and the other week another teacher has accepted. I struggle for changing of this situation. I don't want him to keep away from some activities. They didn't accept my children to painting contest $\left[\mathrm{E}_{14}\right]$ " "There are deficiency for treatment, there's not any speech therapist even if it is difficult and costly to go to Nicosia $\left[\mathrm{E}_{2}\right]$ ". "He was eating the crayons at day care center, and they didn't want to accept him [ $\left.\mathrm{E}_{12}\right]$." "I carried him since four years old. His friends pricked her, locked her into bathroom [ $\left.\mathrm{E}_{18}\right]$." "The other parents didn't want her to accept into the classroom during combining process $\left[\mathrm{E}_{20}\right]$." "Social education shouldn't be for short term. I'd prefer continuous education. I begged to the principal of the elementary school but he didn't accept my child into the school $\left[\mathrm{E}_{5}\right]$." "Schools shouldn't be half of a day, Education should be every day, up to $6 \mathrm{pm}$ and there could be institutions that provide weekend education $\left[\mathrm{E}_{2}\right] . "$

Here are the some statements of parents of mentally disabled children on their education levels:

"I am graduated from primary school. If I could be well educated I can much better understand my child $\left[\mathrm{E}_{20}\right]$." "...We don't know how to take care to our child as parents. It would be better if we could find support on this issue $\left[\mathrm{E}_{15}\right]$." "I wish I would have educated $\left[\mathrm{E}_{19}\right]$." "I want to have graduated from university for much more helpful to my child [ $\left.\mathrm{E}_{16}\right]$."

\subsubsection{Physical Problems}

Physical problems include inappropriate living conditions of mentally disabled children and parents of the, inadequacy of physical environment of them and problems which they confronted during undertaken care responsibility. Here are some statements of participants on physical problems:

One of the parents who have a child diagnosed as spastic has told in one of our interview:

"The greatest problem of us is that we can't move the wheel chair everywhere. There is no ramp in everywhere; therefore I can't move my daughter anywhere. I choose my neighbours from where live in a place proper to move wheel chair... We make our 22 years old daughter have shower with my husband ... [ $\left.\mathrm{E}_{1}\right]$." "She can't walk alone. She needs constant help. My elder son helps to her. But the younger one doesn't. [ $\left.\mathrm{E}_{6}\right]$ ". "She can't sit on toilet. I protect her at school for not to bump the other children to her $\left[\mathrm{E}_{25}\right]$ ". "Therefore our home is near by the road, they go by themselves sometimes. There are no safe places for children to play $\left[\mathrm{E}_{3}\right]$ ". "I have great difficulty when make her shower $\left[\mathrm{E}_{10}\right]$ ". "She can't let know her need to toilet. Sleep less at night. We have more difficulty for her mother employed too $\left[\mathrm{E}_{12}\right]$ ". "I make everything for her. Feeding, make her drinking something etc. $\left[E_{22}\right]$ ". "I have brought him to the teacher at Mersin 45 minute route. We have had great difficulty for public transport was not designed for disabled person. I have same problems in Northern Cyprus too. The public transporters should be designed for disabled person $\left[\mathrm{E}_{4}\right]$ ". "We can't find any responsible person or playing room when we go for shopping to mall $\left[\mathrm{E}_{16}\right]$ ". "There is not any playground around us, even if they are not suitable for our child. I have difficulties when I take him to playground, disabled children are not considered at parks $\left[\mathrm{E}_{8}\right]$ ". "... There is no playground suitable to my child. $\left[\mathrm{E}_{11}\right]$ ”.

\subsubsection{Psychological Problems}

It has been seen that parents have many psychological problems related with their mentally disabled children. It 
has been found that these psychological problems are concentrated on sub categories as sense of self, anxiety and depression. You will find the statements of parents on psychological problems:

"I'm waste away for 15 years. My child still can't walk. HE says 'I wish I can walk and play' $\left[E_{21}\right]$ ". "I'm psychologically worn out. It's difficult for I' struggle by myself for the life. Children miss their father and I cannot console them sometimes, my heart is broken $\left[\mathrm{E}_{2}\right]$ ". "I've struggled for accepting this situation before. I'm a little consoled for now. I can't stay away for a long time from children $\left[\mathrm{E}_{14}\right]$ ". "...It hurts me that my child plays with younger children than her $\left[\mathrm{E}_{17}\right]$ ". "After we were informed that he is disabled, I was the one who has most effected this situation. I couldn't go out from home for one year. $\left[\mathrm{E}_{25}\right]$ ". "I am under stress. The doctor said that my child will never walk and will be dead to the world. I'm so sorry $\left[\mathrm{E}_{10}\right]$ ". "I have concerns for the future of my child $\left[E_{22}\right]$ ". "Both burden of child and the route that we have to go make me worn out. $\left[\mathrm{E}_{4}\right]$ ". "He lives problems in ourselves. We feel sorry if he can't do something else $\left[E_{7}\right]$ ". "He doesn't listen to me. I'm worry about if I would death what would be happening to him $\left[\mathrm{E}_{15}\right]$ ". "We couldn't accept hen we learned that he has autism. We are in depression $\left[\mathrm{E}_{24}\right]$ ". "We can't have meal with her with family. She wants the foods that we have. It makes me worry as a mother $\left[\mathrm{E}_{8}\right]$ ". There is a negative effect on me if someone says to me "God helps you". Sometimes neighbours say "He is a wayward child". It makes me worry. Of course his behaviours affect my neighbours $\left[\mathrm{E}_{5}\right] "$.

\subsubsection{Social Problems}

Socially problems consist of problems with environment of mentally disabled child, reactions from social environment and negative traces that caused by effects of behaviours of the mentally disabled children on environment. Especially social exclusion problem is one of the main problems of these parents. Her are the statements of some participants about sociological problems:

"People surrounded me says for my child as "disabled". My child understands and worries for this statement $\left[E_{21}\right]$ ". "I am refused by neighbours. They don't come to visit me. Even my sister feels uncomfortable with us. I understand from their looks that the other people unwell with my children. $\left[\mathrm{E}_{9}\right]$ ". "Even mothers of disabled child do not threat well to our children with insightfully. Our relationship with our neighbours is too weak $\left[\mathrm{E}_{20}\right]$ ". "When he was a little boy, my son disturbed surrounded people. I meet with people who welcome us. Sometimes people call him as wayward child. Of course these behaviours of my son affect my neighbour $\left[\mathrm{E}_{5}\right]$ ". "My daughter plays alone at playground therefore the other children don't want to play with her $\left[\mathrm{E}_{13}\right]$ ". "Our relationship is good. But when I heard they speak at playground about my child as "cripple child", I feel so worrisome [ $\left.\mathrm{E}_{4}\right]$ ". "People surrounded us for instance our neighbours say "this child is different from the others, however they try to not to make us feel something I can understand that they exclude my child $\left[\mathrm{E}_{19}\right]$ ". "His friends mocking with him... $\left[\mathrm{E}_{3}\right]$ " "WE have trouble in society. Some stores don't let us in. They warn me by saying 'please take care to your child. [E $\left.\mathrm{E}_{4}\right]$ ". "Two families refused to come to our home for my son is disabled. I didn't want to take salary (support for disabled person) of him for not to be branded [ $\left.\mathrm{E}_{6}\right]$ ". "I don't like the reactions of people in the society; it's too sad being an unwanted person by others $\left[\mathrm{E}_{16}\right]$ ". "My wife cannot go to home visit to her friends for they bother my daughter that disturbs my wife too. They come to us but my wife doesn't go anywhere not to cause problem to others $\left[\mathrm{E}_{11}\right]$ ". "Even playground the other children push him, mocks with him or take something in his hands, he cannot run after them, unaccustomed looks of the people affects me so much $\left[E_{17}\right] "$.

\subsubsection{Economic Problems}

Economic problems which parents confronted are material inadequacies for meeting basic needs as education, self - care, nutrition, sheltering and health-care of mentally disabled children. Here are the statements of some participants for economic problems:

"We have monetary problem. We can't go to private care for its very expensive $\left[\mathrm{E}_{21}\right]$ ". "I have additional expenses for transferring to lesson. Money is not enough $\left[E_{25}\right]$ ”. “...There is not any speech therapist even if it's difficult and expensive to go to Nicosia $\left[\mathrm{E}_{2}\right]$ ". "Money support of the state is not enough... $\left[\mathrm{E}_{17}\right]$ ". "We have economical problem, we have to go to doctor. It costs a lot $\left[\mathrm{E}_{15} ; \mathrm{E}_{18} ; \mathrm{E}_{20}\right]$ ". "WE have economic problems. Aleyna doesn't get salary, as I don't get widow pension [ $\left.\mathrm{E}_{16}\right]$ ". "My child cannot eat everything; she has a special dietary program, that's why her foods are very expensive. WE get her foods from Hacettepe. We spend at least $2.000 \mathrm{Tl}$ (two thousand Liras) for her food every month $\left[\mathrm{E}_{8}\right]$ ". "Expenses for my daughter are much more than the support of the State. We go to Turkey every six month for health control; I pay too much [ $\left.\mathrm{E}_{11}\right]$.

\subsubsection{Care and Health-care Problems}

Care and health - care problems include the difficulties which parents experienced to meet necessary needs and struggles for treatment of their children. Here are the 
statements of some participants for care and health-care problems:

"We have problem with care. $\left[\mathrm{E}_{2}\right]$. "We live nearby the road. Sometimes they go out alone, someone should take care them continuously $\left[\mathrm{E}_{3}\right]$ ". "I have difficulties for make her shower $\left[\mathrm{E}_{10}\right]$ ". "She can't let me know her need for toilet. Sleep less at night. WE have difficulties for her mother is working $\left[\mathrm{E}_{12}\right]$ ". "I do everything of her, feeding, and etc. $\left[\mathrm{E}_{22}\right]$ ". "The hardest period that I've experienced was my pregnancy to my son. I couldn't care to my daughter adequately. Sometimes when my husband has gone to work, I couldn't go to toilet even bathroom. I asked someone to care my son for brought my daughter to the doctor. I would be much more comfortable if there was an institute to give care to my son or daughter for some instances $\left[\mathrm{E}_{1}\right]$ ". "There are burdens both with child and the road $\left[\mathrm{E}_{4}\right]$ ". "Her activities are limited for she has cardiac problems $\left[E_{13}\right]$ ". "Doctors don't make explanation. Sometimes they argue with us. We shouldn't be waited when we go to the doctor, but they make us be waited $\left[\mathrm{E}_{15} ; \mathrm{E}_{20}\right]$ ". "He usually falls down and crashes his head somewhere, we move him to hospitals $\left[\mathrm{E}_{22}\right]$ ". "I had many difficulties while going to Adana for doctor at the beginning $\left[\mathrm{E}_{5}\right]$ ". "It needs to be shown more interests to us at hospitals. We shouldn't be waited. There are neurologists in here. Why do they send us to Turkey? $\left[\mathrm{E}_{6}\right]$ ".

\subsubsection{Sibling Problems}

Sibling problems consist from problems of conflicts and emotional reactions between mentally disabled children with other siblings. Here are the statements of some participants on sibling problems:

"He often has conflict with his brother when they play together $\left[E_{25}\right]$ ". "My daughter Nida envies Esra, her sister, sometimes she become angry and shouts. We had problem with elder sister at the beginning. But now she got used to her sister $\left[\mathrm{E}_{13}\right]$ ". "His brother envies her and acts hard to her for his jealousy $\left[E_{14}\right]$ ". "Sometimes there could be uneasiness between siblings. They disturb their each other while studying or doing their homework $\left[\mathrm{E}_{3}\right.$; $\left.\mathrm{E}_{10}\right]$ ". "Sometimes Betul says we love care her sister more than her, envies her and doesn't want to meet her with friends and play with her $\left[\mathrm{E}_{20}\right]$ ". "Always having problem when they come together with her brother, they always have conflict $\left[\mathrm{E}_{16}\right]$ ". "He always disarranges his sisters' things; always fight with her $\left[\mathrm{E}_{8}\right] "$.

In the second sub question of the research we asked to the participants how the stress that they experienced has occurred for determining the signs of stress that emerged on parents of mentally disabled child. Three different categories determined directed to the signs of stress that experienced by parents of mentally disabled children based on answers of participants. These are physical signs, Psychological signs and behavioural signs as respectively.

\subsection{Signs for Stress on Parents of a Mentally Disabled Child}

\subsubsection{Physical Signs}

Physical signs consist from physical changes that caused by experienced stress of parents with mentally disabled child. Here are the statements of some participants on physical signs:

"I have more headaches since I have learned this situation of my child $\left[\mathrm{E}_{4}\right]$ ". "I always feel exhausted and tired $\left[\mathrm{E}_{10}\right]$ ". "I lose weight by thinking the differences of my child, I can't get weight, and I feel tasteless. I live with vitamins $\left[\mathrm{E}_{23}\right]$ ". "My blood pressure is increased for stress, it makes me sick $\left[\mathrm{E}_{16}\right]$ ". "Since I have learnt the problem of my child after delivery there are convulsions on my body, I feel fatigue and exhausted $\left[\mathrm{E}_{19}\right]$ ". "There are itching and skin rashes on my skin. Doctor said that they are resulted of stress $\left[\mathrm{E}_{11}\right]$ ". "I am under stress. I lost my teeth because of stress $\left[\mathrm{E}_{22}\right]$ ".

\subsubsection{Psychological Signs}

Psychological signs are defined as emotional and mentally changes which were caused by experienced stress of parents with mentally disabled child. It's seen that some psychological signs as sadness, anxiety, anger, trouble, lack of self-confidence, forgetfulness, fatigue, abstractedness are come forth on those parents. Some statements of parents for psychological signs are as below:

"In fact I'm a funny person, but when I think about my child I feel sorry and cry for her $\left[\mathrm{E}_{1}\right]$ ". "We go out when I feel bored. WE used to go to cinema, but we are afraid of going to there now. $\left[E_{13}\right]$ ". "I can't control my daughter. I'm worry about it and complain; trying to do housework. Sleep at home, don't want to see anyone. When I look at the daughter of the neighbour I cry for why my daughter is different from the other children. I don't want to entrust her to anyone. I feel stressed myself at home. I can't do anything at home $\left[\mathrm{E}_{20}\right]$ ". "She is not same with her friends. She cannot control over herself. This makes us worry [ $\left[\mathrm{E}_{24}\right]$ ". "I often cry. I don't want him to see me while crying. It makes him sorry $\left[\mathrm{E}_{4}\right]$ ". "I'm worry about his future. The question that who will take care to him is my greatest trouble. [ $\left.\mathrm{E}_{7}\right]$ ". "I have great stress especially because of neighbours. Usually I'm a patient person. I talk with the child sometimes. I cry $\left[\mathrm{E}_{8}\right]$ ".'” I feel confused because of the problem that we experienced; I'm in abstractedness $\left[E_{25}\right]$ ". "Sometimes I feel exhausted and desperate emotionally $\left[\mathrm{E}_{5}\right]$ ". "I was a calm and 
patient person before my son has borne, but now I'm angry, I want to cry $\left[\mathrm{E}_{14}\right]$ ". WE have tension in family, we conflict with my husband frequently, and we hurt our each other $\left[\mathrm{E}_{6}\right]$ ". I become angry and nervous in any case, any mistake. I ask myself how long does it last, I feel very tired $\left[E_{2}\right]$ ". "I could be more hard, angry or aggressive to my other children because of my stress. Then I regret from this attitude $\left[E_{5}\right]$ ". "I go out and walk around. I cry for my sorrow $\left[\mathrm{E}_{25}\right]$ ".

\subsubsection{Behavioural Signs}

Behavioural signs are defined as deterioration of sleeping pattern, consuming cigarette and alcohol, changing on nutrition style related with stress that experienced by parents of mentally disabled child. Statements of some participants on behavioural signs are as below:

"I smoke whenever think about the situation of her, I smoke much more than before the diagnosis $\left[\mathrm{E}_{3}\right]$ ". "Both me and my husband couldn't sleep well at beginning when we have learned her disability $\left[\mathrm{E}_{18}\right]$ ". "Mother, father, grandmother and grandfather... All of us have effected from the situation. Sometimes grandmother cry and become angry and we have shouted to or each other $\left[\mathrm{E}_{12}\right]$ ". "I drink much more than past for not to ask to myself "Why my child have this disability? Why doesn't he healthy like the others?' $\left[E_{7}\right]$ ". "I remember the problem of my child if I don't have something to do, I do housework to forget it $\left[\mathrm{E}_{9}\right]$ ". "I go to playground with my child and slide with him. I listen to the music, read book and distract my attention $\left[\mathrm{E}_{17}\right]$ ".

On the third sub question of the research coping strategies of the parents with mentally disabled child are examined. It's seen that parents with mentally disabled child are apply both strategies which are emotion focused coping and problem focused coping related with situations and conditions. These strategies are collected in three categories which are physical techniques, cognitive techniques and behavioural techniques.

\subsection{Coping Techniques with Stress}

\subsubsection{Physical Techniques}

It's seen that parents have mentally disabled child are apply physical exercises and sportive activities which are directed to physical relaxation for coping with experienced stress. Statements of some participants related with physically coping strategies are below:

"I lay down on the sofa when my stress level increased and try to be relaxed by breathing $\left[\mathrm{E}_{20}\right]$ ". "I lay down on the floor after sending the child to school $\left[E_{15}\right]$ ". "... Thanks to my spouse who doesn't say any bad thing. We do exercise; go around for coping with stress. Go out on Sundays $\left[\mathrm{E}_{1}\right]$ ".
“...Once I cried so much. I walk with my child if I angry for something... $\left[\mathrm{E}_{5}\right]$ ". "I sing loudly to release from stress, dance with music... $\left[\mathrm{E}_{12}\right]$ ".

\subsubsection{Cognitive Techniques}

It's seen that parents who have mentally disabled child prefer emotional approach with resignation in the base of faith for decreasing of the effects as a part of cognitive techniques. Statements of some participants related with cognitive coping strategies are as below:

"Whenever I feel lose my patience, beg to God "Please increase my patience my Lord" $\left[\mathrm{E}_{4}\right]$ ". "Sometimes I assure myself by saying 'Of course it will be ended $\left[E_{10}\right]$ ". "I pray when I feel exhausted, try to comfort myself as there are people who hve much more difficult situation $\left[\mathrm{E}_{13}\right]$ ". "I think about his future sometimes. I worry about who will take care to him. But this is divine providence ... [ $\left[\mathrm{E}_{24}\right]$ ". Our family has good relationship. His sister cares him, He has an uncle, and he could care him. That's my consolation. $\left[\mathrm{E}_{17}\right]$ ". "I accept my experience as "That's my fate, I need to live these events in anyway $\left[\mathrm{E}_{14}\right]$ ". "What's been done, can't be undone, don't mind, nothing so bad but might have been worse," saying myself" $\left[\mathrm{E}_{19}\right]$ ".

\subsubsection{Behavioural Techniques}

It's seen that parents of mentally disabled children get use different behavioural techniques as coping strategies with stress directed to decrease the effect of problem source. Activities as walking around in their spare time, swimming, working in the garden, conversation with neighbours and relatives, reading book, shopping with friends which are putting instance to the source of stress are some of examples for behavioural strategies.

"I go out to the garden, while she is playing I take care the flowers $\left[\mathrm{E}_{17}\right]$ ". "I go out from home and go to the Cafe. $\left[\mathrm{E}_{11}\right]$ ". "I take him to walk around. It makes us calm $\left[\mathrm{E}_{16}\right]$ ". "I watch TV $\left[\mathrm{E}_{6}\right]$ ”. "...we go to swimming $\left[\mathrm{E}_{2}\right]$ ". "... I clean the house when I feel stress. If I feel much angrier I walk around with my child. For now I write my experiences $\left[E_{5}\right]$ ". "I go to my friend to drink coffee, when my child has gone $\left[\mathrm{E}_{22}\right]$ ". "I listen to the music, read book; it distracts my thoughts away from the problem. Sometimes I cry for being relaxed [ $\left.\mathrm{E}_{18}\right]$ ". "If I have time I have shower, dress up and calling one of my friend or my sister then we go for shopping $\left[\mathrm{E}_{9}\right]$ ". "If I feel very angry I entrust the child to her elder sister then go to bedroom and try to be relaxed $\left[\mathrm{E}_{23}\right]$ ". "I go for hunting with my friends at weekends to decrease my stress $\left[\mathrm{E}_{3}\right]$ ".

\section{Conclusions and Discussion}

Strategies for coping with stress of parents of mentally 
disabled child are evaluated by determining of confronted problems. It's found that parents have noticed the disability of their child in first year after birth and faced with stress in this period according to the research. Caring of these children is undertaken by mother of the child and the other family members which that result have paralleled to the result of researches of Gulseren et al. [34] In addition, the age at which parents begin to receive outreach support in order to reduce the impact of the problem is mainly in the period of two to three years of age for their children. These findings overlap with research findings of Bilal and Dağ [21]; Özsoy, Özkahraman and Çallı [35].

Parents of mentally disabled child are confronted multiple problems. According to the finding of the research these problems are educational, physical, sociological, economic problems with care, health-care and sibling problems. İnadequacy or inappropriate conditions of the environment, having difficulties for transportation because of the disability, material and psychological difficulties on self-care of the child, conflicts with the other siblings of mentally disabled child and socially exclusion from their society are determined as the problems of both mentally disabled children and their parents in the research. These results have similarity with the results of the researches of Genç [36] and Kahriman and Bayat [37]. It would be commented as those problems which parents of mentally disabled child are relevant and tangled problems for they have frequency values close to each other. Every problem which those parents faced is related with main stress source. These problems have features that interact and trigger each other. It can be said that the effect of stress caused by mental disability will be diminished by the level of abandonment of the questions.

In the survey, educational problems appeared to be more severe than other problems. It's supposed that the reason of come to the fore of educational issues is a result of the expectation and efforts of parents with mentally handicapped children from education for reduce the stress effect on them that could be help them coping with their experienced problem. The prominent problem of educational ones is enrolment to schools accepting to classrooms for parents with mentally disabled child. Especially for enrolment to the inclusive classes, principals and teachers are reluctant to accept the mentally disabled child in the educational environment. These findings also have similarity with the findings of researches of both Toker [38] and Genç [36]. Parents with mentally disabled children suppose that this reluctance derives from concern of principals of schools and institutes for deterioration of school atmosphere by the mentally disabled child. It's appeared that educational problems that experienced by parents with principals of schools and institutes are important problems which should be elaborated. In another aspect there are negative remarks for qualification and characteristic of the education which is given to the mentally disabled children. The main problems are emphasized as inadequacy of education period, need for special supportive education and exclusion from educational activities of mentally disabled children in this context. Education opportunities and possibilities which are offered to mentally disabled children have shown differences. This situation is incompatible with the right of individuals who come to the age of education to benefit from compulsory education and the principles of equal opportunity in education. The results of research which was performed by Wanjin, Zaihua and Yujuan, [39] support this finding.

The other aspect of educational problem is inefficacy of the formation of parents. This result confirms that the educational levels of parents are at primary and lower levels. Parents are aware that their education is inadequate. Parents, however, have the hope that if the quality and level of education they receive would be higher they would be able to struggle with their children more effectively than they can handle problems. There are researches that support which higher education level and consciousness could increase coping with stress in the level of education and the increase in consciousness levels of the parents and the effect of coping with stress [40, 41, 42]. Hence in this research it's found that parents who have graduated from high school and more have more self - confidence compared to parents with lower educational graduation, also they feel more competence for caring and training of their children and coping easily with the difficulties and have less stress effect when they compared with the other group. It can be said that increasing of educational level of parents help them to use proactivemethods for struggle with problems and copingwith stress.

Parents give priority to educational problems more than others. This can be interpreted as an effort to reduce the stress caused by the disability by means of education for children. However, according to the results of this research that education of disabled children should be carried out in a more qualified and lasting structure in order to overcome social exclusion problem that parents experienced and to reduce the anxious for future of their children. Having social pressure, trouble with integrating to the society and insensitive attitudes of surrounding peoples could be interpreted as exposing to social exclusion of families of children with mental disability. Mental disability causes exclusion of families and this is argued in findings of researches of Genç and Dalkılıç [43], Luescher, Dede, Gitten, Fennell and Maria [44] and Sarı [45]. It is seen that experiencing of social exclusion has a stress increasing effect on parents. Another factor addition to social exclusion which increase the sress burden on families is less income of families. Another result of the research is that parents are inadequate to meet the needs as self-care, nutrition, health-care, education and an effective 
variable on creating stress is economic problems [36, 46]. The obligation of constantly deal with disabled children cause anxiety and burnout effect on parents. Especially anxiety and concerns for the future of their children are the basis of the psychological problems. This finding is parallel wih the findings of Özmen and Çetinkaya [46].

It's found that stress symptoms of parents with mentally disabled child are psychological, physical and behavioural symptoms in this study. The effects of the problems which developed according to main and relative stress sources are emerged as psychological symptoms. Sadness, concern, anger, tribulation anxiety, lack of self-confidence, forgetfulness, burnout, daydreams are includes psychological symptoms.

Physical symptoms are physical changes which are results of experienced stress on their organism; behavioural symptoms are changes on behaviours as consuming cigarette and alcohol, deterioration of sleeping pattern and nutrition balance.

Main stress source for parents is having mentally disabled child. The research found that parents who have children diagnosed with mental disability were first trying to understand what this situation meant for them. The effort to give a sense to this problem can be interpreted in the form of an assessment of the existence of a life-long source of stress. Parents confronting with this situation examine what they can do in the face of this problem. The purpose of this query is a decision phase as to whether the problem is controllable. Parents, who meet the fact that mental disability is an uncontrollable problem, use methods that focus on their emotions in order to reduce the stress reactions they experienced or help them to cope more easily. These findings are in agreement with Folkman and Lazarus [17] cognitive evaluation theory.

Because of mental disability is irreversible and irreparable, parents give new sense to the situation instead of trying to change the problem directly; they develop some attitudes to regulate their feelings related with stress and to reduce or remove stress In the emotion-focused strategy of coping with stress. Beside of these, parents more likely resort to problem oriented strategies for struggling with external problems. It's found that, parents get use physical, cognitive and behavioural techniques for both strategies in order to get rid of the stress. The physical techniques that parents use coping with stress which they experienced are physical exercises to relieve body, muscle relaxation exercises, deep breathing techniques and various sportive activities. Parents have behavioural techniques as leisure time activities, social support from immediate surroundings, moving away to different environments from stress source. Parents seem to use cognitive methods as cognitive techniques, such as accepting the situation on the basis of beliefs, linking to the fate, developing optimistic approaches and patience as compared to greater problems.

As a result, mental disability is a lifelong, irreparable problem source. But there is a great responsibilities and duties to families, educational institutions, educational administrators and educators and policy makers for mentally disabled individuals to continue their independent lives, to become self-sufficient, to integrate with society. There is a need for proper educational ambiance by determining the necessity both of their children and them who are the parents of mentally disabled children to successfully cope with stress. It's thought that improving educational and non-formal education opportunities for both mentally disabled individuals and their parents would be effective in coping with the problem. In addition to this it's necessary to increase the psycho-social support services which could help to cope with stress and to raise social awareness for the social exclusion problem. It's thought that providing qualified and continuous education service for both mentally disabled children and their families could direct both of them to the problem - focused stress coping strategies by moving away from emotion - focused stress coping strategies.

\section{REFERENCES}

[1] Er, M. (2006). Çocuk, hastalık, anne babalar ve kardeşler. Çocuk Sağlığı ve Hastalıkları Dergisi, 49, 155-168.

[2] Eripek, S. (2012). Zihinsel yetersizliği olan çocuklar. Ankara: Pegem.

[3] Sucuoğlu, B. (2009). Zihin engelliler ve eğitimleri. Ankara: Kök.

[4] MEB ORGM. (2009). Özel Eğitim Hizmetleri Yönetmeliği. Ankara: Milli Eğitim Bakanlığı.

[5] Tekinarslan, İ. Ç. (2016). Zihinsel yetersizliği olan ögrenciler. İ. H. Diken içinde, Özel eğitime gereksinim olan öğrenciler ve özel eğitim (s. 140). Ankara: Pegem Akademi.

[6] Tutar, H. (2016). Kriz ve stres ortamında yönetim. İstanbul: Seçkin.

[7] Örnek, A. Ş., \& Aydın, Ş. (2008). Kriz ve stres yönetimi. Ankara: Detay.

[8] Baltaş, A., \& Baltaş, Z. (2016). Stresle başa çıkma yolları. Ankara: Remzi.

[9] Aydın, İ. (2008). İş yaşamında stres. Ankara: Pegem A.

[10] Şahin, N. H. (2010). Stresle başa çıkma. Ankara: Türk Psikologlar Derneği.

[11] Kulaksızoğlu, A. (2016). Farklı gelişen çocuklar. Ankara: Nobel.

[12] Özgen, E. (2003). İletişim ve liderlik. İletişim Dergisi(18), 99-119.

[13] Koç, M. (2002). Gelişim psikolojisi açısından yaşlılık döneminde ruhsal gelişim. Erciyes Üniversitesi Sosyal 
Bilimler Enstitüsü Dergisi, 12(5), 287-304.

[14] Firat, N. (2015). Yurtta veya ailesinin yanında kalan öğrencilerin sosyal destek düzeyleri ve stresle başa çıkma stillerinin incelenmesi. Yüksek Lisans Tezi. Tokat: Gaziosmanpaşa Üniversitesi Eğitim Bilimleri Enstitüsü.

[15] Masuda, M., \& Holmes, T. H. (1978). Life events: perceptions and frequencies. Psychosomatic Medicine, 40(3), 236-261.

[16] Friedrich, W. N., Wilturner, L. T., \& Cohen, D. S. (1985). Coping resources and parenting mentally retarded children. American Journal of Mental Deficiency, 90(2), 130-139.

[17] Folkman, S., \& Lazarus, S. R. (1985). If it changes it must be a process: Study of emotion and coping during three stages of a college examination. Journal of Personality and Social Psychology, 48(1), 150-170.

[18] Onbaşığlu, M. (2004). Stresle baș etmede zihinsel yöntemler. Türk Psikoloji Bülteni (10), 34-35.

[19] Parmaksız, İ., \& Avşaroğlu, S. (2012). Öğretmen adaylarının benlik saygısı düzeylerine göre iyimserlik ve stresle başaçıkma stillerinin incelenmesi. İlkögretim Online, 11(2), 543-555.

[20] Yerlikaya, N. (2007). Lise öğrencilerinin mizah tarzları ile stresle başa çıkma tarzları arasındaki ilişkinin incelenmesi. Yüksek Lisans Tezi . Adana: Çukurova Üniversitesi Sosyal Bilimler Enstitüsü.

[21] Bilal, E., \& Dağ, İ. (2005). Eğitilebilir zihinsel engelli olan ve olmayan çocukların annelerinde stres, stresle başa çıkma ve kontrol odağının karşılaştırılması. Çocuk ve Gençlik Ruh Sağlığı Dergisi, 12(2), 56-68

[22] Uğuz, S.., Toros, F., İnanç, B. Y., \& Colakkadığlu, O. (2004). Zihinsel ve/veya bedensel engelli çocukların annelerinin anksiyete, depresyon ve stres düzeylerinin belirlenmesi. Klinik Psikiyatri, 7(1), 42-47.

[23] Akçakın, M., \& Erden, G. (2001). Otizm tanısı konmuş çocukların anne - babalarındaki ruhsal belirtiler. Çocuk Ruh Sağlı̆̆ 1 Dergisi, 8(1), 2-10.

[24] Aslan, Ç. (2010). Zihinsel engelli çocuğu olan ane babaların psikolojik belirtileri, sosyal destek algıları ve stresle başa çıkma tarzlarının karşılaştırılması. Yüksek Lisans Tezi. İstanbul: Maltepe Üniversitesi Sosyal Bilimler Enstitüsü.

[25] Çopuroğlu, Y. C., \& Mengi, A. (2014). Toplumsal dışlanma ve otizm. Turkish Studies - International Periodical for the Languages, Literature and History of Turkish or Turkic, 9(5), 607-626.

[26] Dyson, L. (1997). Fathers and mothers of school-age children with developmental disabilities: Parental stress, family functioning, and social support. American journal on mental retardation, 102(3), 267-279.

[27] Lusting, D. (1999). Family care giving of adults with mental retardation: Key issues for rehabilitation. The Journal of Rehabilitation (1), 20-40.

[28] Scott, B. S., Atkinson, L., Minton, H. L., \& Bowman, T. (1997). Psychological distress of parents of infants with Down syndrome. American Journal on Mental Retardation, 102(2), 161-171.
[29] Şengül, S., \& Baykan, H. (2013). Zihinsel engelli çocukların annelerinde depresyon, anksiyete ve stresle başa çıkma tutumları. Kocatepe Tip Dergisi, 14(1), 30-39.

[30] Yavuz, F. (2016). Zihinsel engelli çocuğu olan ailelerin karşılaştıkları sosyal dışlanma sorunsalı üzerine bir araştırma. Yüksek Lisans Tezi. Muğla: Muğla Sitkı Koçman Üniversitesi Sosyal Bilimler Enstitüsü.

[31] Yıldırım, A., Şimşek, H. (2016). Nitel araştırma Yöntemleri, Seçkin, Ankara.

[32] Patton, M. Q. (1987). How to use qualitative methode in evaluation. Newbury Parc: CA: Sage.

[33] Miles, M. B., \& Huberman, A. M. (1994). Qualitative data analysis: An expended sourcebook. California: Sage.

[34] Gülseren, L., Çam, B. K., Yiğit, T., Danacı, A. E., Çubukçuoğlu, Z., \& Taş, C. (2010). Gülseren, L., Çam, B., Karakoç, B., Yiğit, T., Danacı, A. E., Çubukçuoğlu, Z. \& Mete, L. Şizofrenide ailenin yükünü etkileyen etmenler. Türk Psikiyatri Dergisi, 21(3), 203-212.

[35] Özsoy, S. A., Özkahraman, Ș., \& Çallı, F. (2006). Zihinsel engelli çocuk sahibi ailelerin yaşadıkları güçlüklerin incelenmesi. Sosyal Politika Çalışmaları Dergisi, 8(9), 69-77.

[36] Genç, Y. (2015). Engellilerin sosyal sorunları ve beklentileri. Sosyal Politika Çalışmaları Dergisi, 35(2), 65-92.

[37] Kahriman, İ., \& Bayat, M. (2008). Özürlü çocuğa sahip ebeveynlerin yaşadıkları güçlükler ve algıladıkları sosyal destek düzeyleri. Özveri Dergisi, 5(1).

[38] Toker, M. (2016). Down sendromlu çocuğa sahip annelerin aile gereksinimlerinin belirlenmesi ve sosyal destek algılarına yönelik görüşleri. Yüksek Lisans Tezi. Gaziantep: Hasan Kalyoncu Üniversitesi, Sosyal Bilimler Enstitüsü.

[39] Wanjin, M., Zaihua, L., \& Yujuan, L. (2007). There Is still a long way to go: Putting forward equity in disabled children education - The Fourth comment on equity in disabled children education. Chinese Journal of Special Education, 2(001), 2-12.

[40] Ayyıldız, T., Şener, D. K., Kulakçı, H., \& Veren, F. (2012). Zihinsel engelli çocuğa sahip annelerin stresle baş etme yöntemlerinin değerlendirilmesi. Ankara Sağlık Hizmetleri Dergisi, 11(2), 1-12.

[41] Karaaslan, M. M. (2015). Zihinsel engelli çocuğu olan ebeveynlerin psikolojik durumları ile bakım yükünün değerlendirilmesi. Yüksek Lisans Tezi. Erzurum: Atatürk Üniversitesi, Sağlık Bilimleri Enstitüsü.

[42] Telef, B. B. (2013). Engelli çocuğa sahip ebeveynlerin öz-yeterliklerinin ve psikolojik belirtilerinin incelenmesi. Erzincan Üniversitesi Eğitim Fakültesi Dergisi, 33-49.

[43] Genç, Y., \& Dalkılıç, P. (2013). Yaşlıların sosyal dışlanma sendromu ve toplumsal beklentileri. The Journal of Academic Social Science Studies International Journal of Social Science-JASSS, (6), 461-482.

[44] Luescher, J. L., Dede, D. E., Gitten, J. C., Fennell, E., \& Maria, B. L. (1999). Parental burden, coping, and family functioning in primary caregivers of children with Joubert syndrome. Journal of Child Neurology, 14(10), 642-648. 
[45] Sarı, H. Y. (2007). Zihinsel engelli çocuğu olan ailelerde aile yüklenmesi. Cumhuriyet Üniversitesi Hemşirelik Yüksekokulu Dergisi, 11(2), 1-7.
[46] Özmen, D., \& Çetinkaya, A. (2012). Engelli çocuğa sahip ailelerin yaşadığ 1 sorunlar. Ege Üniversitesi Hemşirelik Fakütesi Dergisi, 28(3), 35-49. 